\title{
Hyperinsulinemia during oral glucose tolerance test and high normal serum cortisol are associated with increased secretion of calcitonin in normal subjects
}

\author{
Antonis Polymeris, Peter D. Papapetrou, Fotini Papandroulaki, Stavroula Thanou
}

Second Division of Endocrinology, Alexandra Hospital, Athens, Greece

\begin{abstract}
OBJECTIVE: Previous studies showed that insulin stimulated directly calcitonin $(\mathrm{Ct})$ secretion in the pig thyroid, while dexamethasone stimulated the production of $\mathrm{Ct}$ and $\mathrm{Ct}$ mRNA in medullary thyroid carcinoma (MTC) cell lines. The objective of this study was to investigate if hyperinsulinemia during the oral glucose tolerance test (GTT) stimulates Ct secretion in normal subjects as well as to examine the relationship between serum cortisol and Ct. DESIGN: In 26 normal subjects ( 9 men and 17 women) with detectable basal serum $\mathrm{Ct}$, aged 22-70 yr [51.5 \pm 14.6 (mean \pm SD), median 55.5], we measured serum or plasma $C t$, cortisol, ACTH, insulin, and blood glucose before $(0 \mathrm{~min})$ and at 30, 60, 90, and $120 \mathrm{~min}$ after ingestion of 75 g glucose. RESULTS: During GTT mean serum cortisol increased slightly by $9.3 \%$ at 30 min, whereas mean serum insulin increased 9.4-fold, reaching a peak value at $60 \mathrm{~min}$. Median serum Ct increased by $51 \%(p<0.001)$ in normal subjects (by $27 \%$ in men, $p=0.004$, and by $44 \%$ in women, $p<0.001$ ) at $30 \mathrm{~min}$ and remained significantly higher thereafter (up to $120 \mathrm{~min}$ ) when compared to median baseline level. Regression analysis showed that basal serum cortisol, but not basal serum insulin, was correlated with basal serum $C t(p=0.01)$. Peak concentrations of $\mathrm{Ct}$ were also correlated with peak concentrations of cortisol at $30 \mathrm{~min}(\mathrm{p}<0.001)$ but not at later time points. Serum insulin was correlated with serum $\mathrm{Ct}$ at the serum insulin peak level $(60 \mathrm{~min})$, and at later time points $(90$ and $120 \mathrm{~min})(\mathrm{p}=0.001)$. Multiple and simple regression analysis showed that calcitonin-AUC (Area Under Curve) values correlated with insulin-AUC $(p=0.003)$, and also with cortisol-AUC $(p=0.02)$ values, the standardized effect of insulin-AUC on Calcitonin-AUC being greater than that of cortisol-AUC. CONCLUSIONS: These findings suggest that acute hyperinsulinemia during GTT is very likely associated with increased Ct secretion in normal subjects. Serum cortisol within the physiological range was also correlated with serum Ct under basal conditions, as well as during GTT.
\end{abstract}

Key words: Calcitonin secretion, Cortisol, Glucose tolerance test, Hyperinsulinemia, Insulin 


\section{INTRODUCTION}

Calcium and gastrin are established calcitonin (Ct) secretagogues. Acute hypercalcemia induced by calcium infusion or infusion of the synthetic analogue pentagastrin have long been used in Ct stimulation tests for the diagnosis of medullary thyroid carcinoma (MTC). Care et $\mathrm{al}^{1}$ demonstrated that in the pig insulin administered in the thyroid artery directly stimulated the secretion of $\mathrm{Ct}$; increasing endogenous insulin during glucose administration had a similar effect. ${ }^{1}$ Dexamethasone stimulated the production and secretion of $\mathrm{Ct}$ in a rat MTC cell line ${ }^{2}$ and also the production of $\mathrm{Ct} \mathrm{mRNA}^{3}$ and calcitonin ${ }^{4}$ in a human MTC cell line. The aim of our work was to investigate if serum $\mathrm{Ct}$ in humans is affected by serum insulin and serum cortisol levels. For this purpose, the response of serum $\mathrm{Ct}$ to hyperinsulinemia induced during the oral glucose tolerance test (GTT) in normal subjects was evaluated. The present work provides evidence that hyperinsulinemia induced during GTT stimulates secretion of calcitonin as indicated by the correlation between high serum insulin levels and serum Ct during GTT. Serum cortisol within the physiological range was also correlated with serum Ct.

\section{SUBJECTS AND METHODS}

The thirty-three healthy normal subjects who participated in the study were divided into two groups. Group A comprised 26 subjects ( 17 women and 9 men) aged 22-70 yr [51.5 $\pm 14.6($ mean \pm SD), median age 55.5], with detectable basal serum Ct and Body Mass Index (BMI) 29.1 \pm 5.1 (mean $\pm S D$, range 21.5-39.0, median 29.7). The age of normal men was $22-70 \mathrm{yr}$ (50.9 \pm 16.4 , median 56) and of normal women 26-70 yr (51.8 \pm 14.1 , median 55). In group B seven healthy women aged 19-62 yr (38 \pm 13.8 , median 36) with nondetectable basal serum Ct were included. The cut-off value for detectable or non-detectable serum $\mathrm{Ct}$ was $2 \mathrm{pg} / \mathrm{ml}$ (the functional sensitivity of the assay).

Subjects with fasting blood glucose higher than $125 \mathrm{mg} / \mathrm{dl}$ were excluded from the study. All subjects were biochemichally euthyroid and had normal results of general blood biochemical tests. None of the participants was taking drugs known to affect glucose metabolism or the secretion of $\mathrm{Ct}$ and none was an active smoker. All the subjects were placed on a diet containing at least $250 \mathrm{~g}$ carbohydrates per day for 3 days before testing. After an overnight fast an oral GTT was performed at $9.00 \mathrm{AM}$ with $75 \mathrm{~g}$ of glucose diluted in $200 \mathrm{ml}$ of water. For an hour before and during the GTT, the participants reclined in a supine position carrying a venous catheter. Blood samples were drawn from an antecubital vein before (0 min) and 30, 60, 90, and 120 minutes after drinking the glucose solution. Blood glucose was measured shortly after collection of the blood specimens. Plasma or serum specimens were stored at $-20^{\circ}$ until assayed for insulin, calcitonin, ACTH, and cortisol.

The study protocol was approved by the Scientific Committee of the Alexandra Hospital and informed consent was obtained from all the participants after an explanation of the study to them.

Blood glucose was measured by an automatic analyzer (Cobas Integra 400 plus) and serum insulin by electrochemiluminescence immunoassay (ECLIARoche Diagnostics GmbH, D-68298 Mannheim) with analytical sensitivity $0.2 \mathrm{U} / \mathrm{L}$. Serum calcitonin was measured by chemiluminescence - Nichols Advantage calcitonin immunoassay which detects mainly the CT (1-32) monomer $^{5}$ with a functional sensitivity $2 \mathrm{pg} / \mathrm{ml}$. Plasma ACTH was determined by chemiluminescenceImmulite 2000, DPC, with analytical sensitivity 5 $\mathrm{pg} / \mathrm{ml}(1.1 \mathrm{pmol} / \mathrm{L})$. Serum cortisol was measured by a solid phase RIA (Coat-A-Count, Diagnostic Products Corporation, Los Angeles, CA, USA) with within assay CV $4 \%$ at the level of $331 \mathrm{nmol} / \mathrm{l}$. All the measurements for each hormone were performed in the same assay.

\section{Statistical analysis}

The changes in each of the various parameters during the oral GTT were evaluated by comparing the values at each time point with the corresponding baseline value using the paired test for the other parameters and the non-parametric Wilcoxon matched pairs test for serum $\mathrm{Ct}$ because of the skewed distribution of serum $\mathrm{Ct}$ concentrations. Comparison of serum $\mathrm{Ct}$ between men and women was made using the Mann Whitney test. The relationship between two parameters during oral GTT was assessed from three points of view: the baseline values, the peak values, and the Area Under Curve (AUC) 0 to 120 min. Relationships between two variables or be- 
tween one dependent variable and more than one independent variable were simultaneously evaluated using simple linear regression or multiple regression analysis, respectively. Normality of the data was evaluated using the KS normality test, the D'Agostino \& Pearson omnibus normality test, and the ShapiroWilk normality test. For the parameters that passed normality tests Pearson correlation coefficients were used, while Spearman correlation coefficients were used for parameters without normal distribution. A two-tailed $\mathrm{p}<0.05$ was considered as significant. Statistical analysis was performed using GraphPad Prism Software, San Diego, CA, USA.

\section{RESULTS}

\section{Changes in serum levels of various parameters during oral GTT}

In all the subjects with non-detectable basal serum $\mathrm{Ct}$ (group B) serum Ct remained non-detectable throughout the GTT and these patients were excluded from further consideration. The results from the 26 normal subjects with detectable basal serum $\mathrm{Ct}$ (group A) are discussed in the present study. The numeric results in each of various parameters during the oral GTT are shown in Table 1, and graphically in Figure 1.

\section{Changes in blood glucose}

Baseline blood glucose in all participants varied between 80 and $123 \mathrm{mg} / \mathrm{dl}$ and attained a mean peak value at $60 \mathrm{~min}$. Mean blood glucose concentration increased as expected and was significantly different at all the subsequent time points when compared to $0 \min (\mathrm{p}<0.001)$.

\section{Changes in serum insulin}

Mean serum insulin increased 9.4-fold reaching its peak value at $90 \mathrm{~min}$ and was significantly higher at all time points when compared to $0 \min (\mathrm{p}<0.001)$.

\section{Changes in serum cortisol}

In the entire group of normal subjects $(n=26)$ mean serum cortisol tended to increase to a peak value at $30 \mathrm{~min}$, thereafter falling slowly to levels below the baseline level at 90-120 min. However, the rise of mean serum cortisol was not statistically significant (increase of $9.3 \%$ at $30 \mathrm{~min}$ ), while its fall at $120 \mathrm{~min}$ was indicative $(p=0.063)$ (Figure 1$)$. Thirteen participants ( 8 women and 5 men) in whom serum cortisol increased during GTT were included in a subgroup designated "cortisol-increased"; in these subjects mean serum cortisol increased significantly by approximately $51 \%$ at $60 \mathrm{~min}(\mathrm{p}<0.001)$ during GTT. In the other 13 subjects ( 9 women and 4 men) serum cortisol decreased during GTT and they were included in a subgroup designated "cortisol-decreased"; in this subgroup mean serum cortisol decreased significantly by $27 \%$ at $60 \mathrm{~min}(\mathrm{p}<0.001)$ (Figure 2$)$. The serum $\mathrm{Ct}$ response to GTT in these two subgroups was also evaluated separately (see below). It should be noted that the increases in mean serum cortisol in the entire group as well as in the subgroups of the participants were within the normal range for morning serum cortisol (Table 1 and Figure 2).

Table 1. Changes in serum (blood, plasma) levels of various parameters during the oral glucose tolerance test

\begin{tabular}{lccccccc}
\hline & & \multicolumn{7}{c}{ Time $(\mathbf{m i n})$} \\
\cline { 3 - 8 } Parameter & $\mathbf{n}$ & $\mathbf{0}$ & $\mathbf{3 0}$ & $\mathbf{6 0}$ & $\mathbf{9 0}$ & $\mathbf{1 2 0}$ & AUC \\
\hline Glucose $(\mathrm{mg} / \mathrm{dl})$ & 26 & $91.8 \pm 2.5$ & $\mathbf{1 5 9 . 8} \pm \mathbf{8 . 0}$ & $\mathbf{1 6 4 . 3} \pm \mathbf{1 4 . 8}$ & $\mathbf{1 4 4 . 7} \pm \mathbf{1 3 . 9}$ & $\mathbf{1 2 8 . 2} \pm \mathbf{1 2 . 2}$ & $17.4 \pm 1.2$ \\
Insulin $(\mathrm{U} / \mathrm{L})$ & 26 & $8.3 \pm 1.0$ & $\mathbf{5 3 . 8} \pm \mathbf{4 . 8}$ & $\mathbf{6 5 . 9} \pm \mathbf{8 . 1}$ & $\mathbf{7 7 . 7} \pm \mathbf{1 1 . 0}$ & $\mathbf{6 6 . 0} \pm \mathbf{1 1 . 5}$ & $7.0 \pm 0.7$ \\
ACTH $(\mathrm{pg} / \mathrm{ml})$ & 26 & $14.4 \pm 2.8$ & $24.5 \pm 9.3$ & $16.4 \pm 3.2$ & $12.2 \pm 1.5$ & $13.1 \pm 1.9$ & $2.0 \pm 0.4$ \\
Cortisol $(\mathrm{nmol} / \mathrm{L})$ & 26 & $301 \pm 16.7$ & $329 \pm 26.3$ & $326 \pm 30.3$ & $296 \pm 21.4$ & $\mathbf{2 6 0} \pm \mathbf{2 0 . 5}$ & $37.0 \pm 2.5$ \\
Calcitonin $(\mathrm{pg} / \mathrm{ml})$ & 26 & $7.1(4.5-13.9)$ & $\mathbf{1 0 . 7}(\mathbf{5 . 7}-18.1)$ & $\mathbf{1 0 . 0}(\mathbf{5 . 1}-16.4)$ & $\mathbf{9 . 7}(\mathbf{5 . 7 - 1 7 . 1})$ & $\mathbf{8 . 4}(\mathbf{5 . 6}-\mathbf{1 5 . 9})$ & $1.1(0.7-2.0)$ \\
Calcitonin, men & 9 & $13.5(8.1-15.7)$ & $\mathbf{1 7 . 2}(\mathbf{1 1 . 1 - 2 3 . 4})$ & $13.2(9.0-19.0)$ & $13.5(8.3-21.9)$ & $\mathbf{1 6 . 1}(\mathbf{9 . 3}-\mathbf{2 2 . 9})$ & $1.8(1.1-2.4)$ \\
Calcitonin, women. & 17 & $5.9(3.8-11.1)$ & $\mathbf{8 . 5}(\mathbf{4 . 8}-\mathbf{1 5 . 6})$ & $\mathbf{7 . 2}(\mathbf{4 . 9}-\mathbf{1 3 . 4})$ & $\mathbf{6 . 4}(\mathbf{4 . 8}-\mathbf{1 3 . 1})$ & $7.0(4.4-12.5)$ & $0.8(0.5-1.6)$ \\
\hline
\end{tabular}

The data presented are: for calcitonin the median (interquartile range) and for the other parameters mean \pm SEM. AUC: Area under curve; arbitrary units. Bold numbers show statistically significant (or indicative) difference from the respective 0 min. 

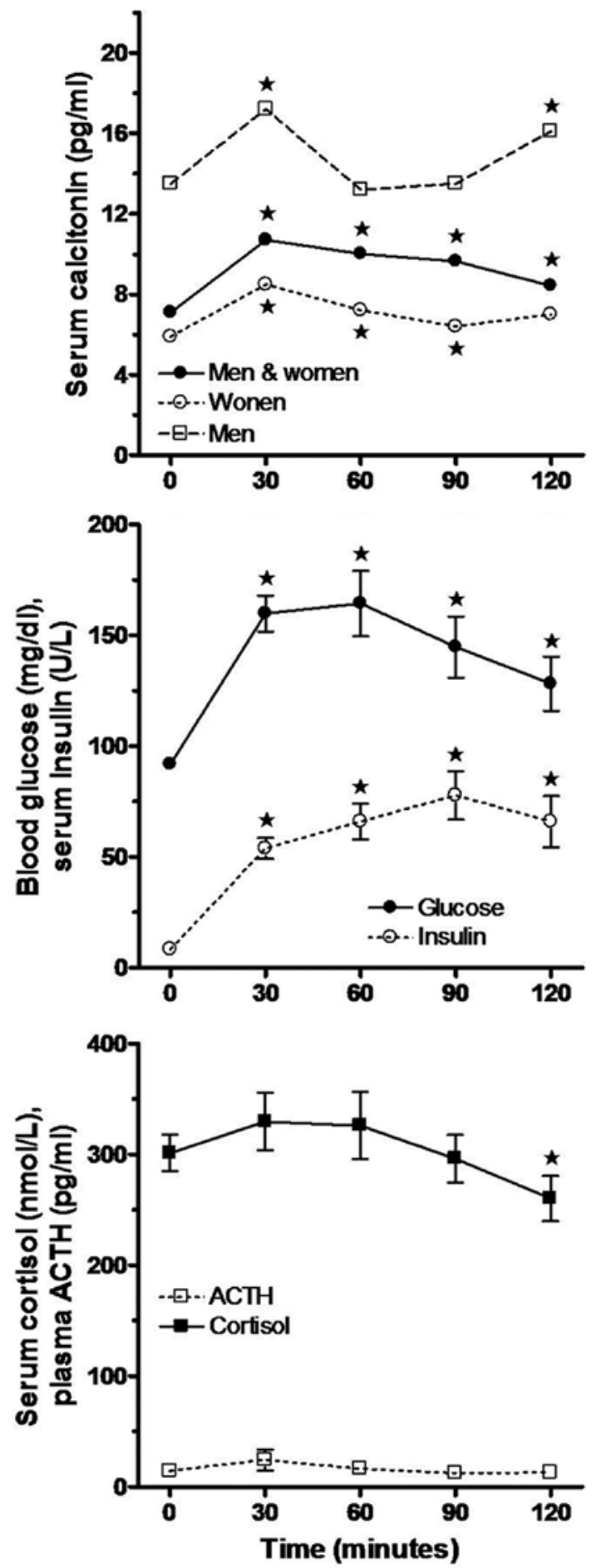

Figure 1. Changes in mean \pm SEM of blood glucose, serum insulin, serum cortisol, plasma ACTH, and median value of serum calcitonin during oral GTT in normal subjects with detectable basal serum calcitonin. Serum calcitonin changes are illustrated separately for normal men $(n=9)$, normal women $(\mathrm{n}=17)$, and all participants $(\mathrm{n}=26)$. The asterisk $\left({ }^{*}\right)$ denotes significant difference from the respective 0 min value (Paired $t$ test or Wilcoxon matched pairs test).
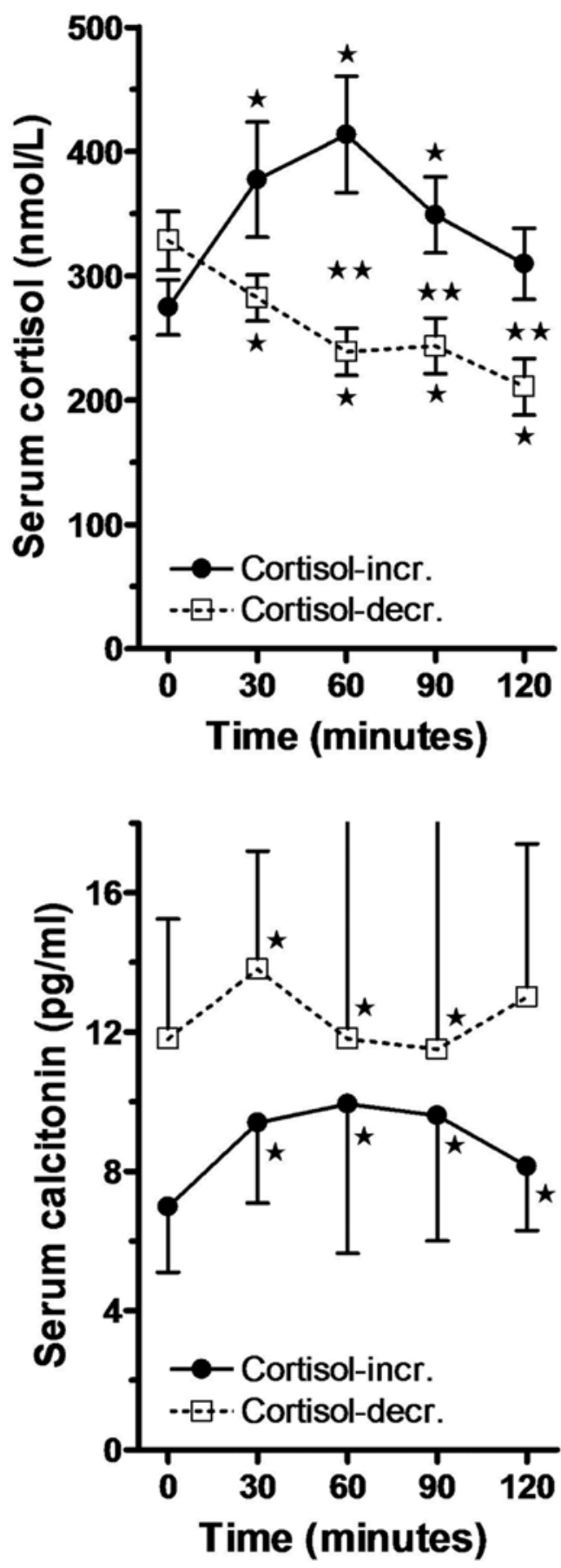

Figure 2. Changes in mean \pm SEM of serum cortisol and the median (interquartile range) value of serum calcitonin in two subgroups: Cortisol-incr. signifies subjects in whom serum cortisol increased $(n=13)$, and cortisol-decr. subjects in whom serum cortisol decreased $(n=13)$ during oral GTT. One asterisk denotes significant difference from the corresponding $0 \mathrm{~min}$ value (Paired t test or Wilcoxon matched pairs test), and two asterisks denote significant difference between the corresponding values of the two groups at each time point ( $\mathrm{t}$ test or Mann Whitney test). 


\section{Changes in plasma ACTH}

The change of mean plasma ACTH, which was similar to that of serum cortisol, was not statistically significant throughout the GTT.

\section{Changes in serum calcitonin}

Basal median serum Ct in normal men $(n=9)$ was indicatively higher $(\mathrm{p}=0.059)$ when compared to basal median serum $\mathrm{Ct}$ in normal women $(\mathrm{n}=17)$, and during GTT it remained significantly higher in normal men when compared to normal women at $30 \mathrm{~min}(\mathrm{p}=0.033), 90 \mathrm{~min}(\mathrm{p}=0.056)$, and $120 \mathrm{~min}$ $(p=0.015)$. The median calcitonin-AUC in normal men was also significantly higher when compared to median calcitonin-AUC in normal women $(p=0.052)$ (Mann Whitney test). Changes in median serum $\mathrm{Ct}$ concentration during GTT are shown in the entire group $(n=26)$ and separately in normal men and women in Table 1, and graphically in Figure 1.

In the entire group of normal subjects $(n=26)$ median serum $\mathrm{Ct}$ increased significantly by approximately $51 \%$ at its peak level at $30 \mathrm{~min}(\mathrm{p}<0.001)$ and remained significantly higher thereafter throughout the GTT when compared to 0 min $(\mathrm{p}<0.001)$ (Wilcoxon matched pairs test); similarly, median serum $\mathrm{Ct}$ increased significantly by $27 \%(\mathrm{p}=0.004)$ in normal men $(n=9)$ and by $44 \%$ in normal women $(n=17$, $\mathrm{p}<00001$ ) (Table 1 and Figure 1). In the subgroup called "cortisol-increased", median serum Ct increased significantly by $42 \%(\mathrm{p}<0.001)$ at $30 \mathrm{~min}$ compared to an increase by $17 \%(\mathrm{p}=0.003)$ in the subgroup called "cortisol-decreased" (Figure 2).

\section{Relation of serum calcitonin with serum levels of various independent predictor variables during oral GTT}

In the entire group of normal subjects $(n=26)$ multiple regression analysis of the baseline serum $\mathrm{Ct}$ values simultaneously on the basal values of serum insulin, cortisol, plasma ACTH, and blood glucose resulted in a coefficient of determination $\mathrm{R}^{2}=0.30$ $(p=0.10)$ (Table 2). By eliminating one by one the non-significant independent variables it was concluded that the only significant predictor of basal serum $\mathrm{Ct}$ was basal serum cortisol with a regression coefficient $\mathrm{R}^{2}=0.24(\mathrm{p}=0.01)$ (Table 3). Similarly, multiple regression yielded for the peak (30 min) values $R^{2}=0.47$, $\mathrm{p}=0.007$, for the $60 \mathrm{~min}$ values $\mathrm{R}^{2}=0.48, \mathrm{p}=0.006$, for the 90 min values $\mathrm{R}^{2}=0.38, \mathrm{p}=0.035$, and for the 120 min values $R^{2}=0.33, p=0.071$ (Table 2 ). However, after the elimination procedure the only significant predictor of the peak (30 $\mathrm{min}$ ) serum $\mathrm{Ct}$ was found to be the $30 \mathrm{~min}$ serum cortisol with a regression coefficient $R^{2}=0.42(p<0.001)$, the only significant predictor of the $60 \mathrm{~min}$ serum $\mathrm{Ct}$ proved to be the 60 min serum insulin with a regression coefficient $\mathrm{R}^{2}=0.40(\mathrm{p}=0.001)$, the only significant predictor of the $90 \mathrm{~min}$ serum $\mathrm{Ct}$ was found to be the $90 \mathrm{~min}$ serum insulin with a regression coefficient $\mathrm{R}^{2}=0.27$ $(p=0.006)$, and the only significant predictor of the 120 min serum $\mathrm{Ct}$ was serum insulin with a regression

Table 2. Normal subjects $(n=26)$

A. Standardized regression coefficients (beta coefficients) from the equations of multiple regression of serum calcitonin on four independent predictor variables during oral glucose tolerance test. The six equations concern $0 \mathrm{~min}, 30 \mathrm{~min}, 60 \mathrm{~min}, 90 \mathrm{~min}, 120 \mathrm{~min}$, and Area Under Curve (AUC) values

\begin{tabular}{|c|c|c|c|c|c|c|}
\hline Predictor variable & $0 \mathrm{~min}$ & $30 \mathrm{~min}$ & $60 \mathrm{~min}$ & $90 \mathrm{~min}$ & $120 \mathrm{~min}$ & AUC \\
\hline Insulin & 0.179 & 0.226 & 0.702 & 0.592 & 0.436 & 0.527 \\
\hline Cortisol & 0.403 & 0.513 & 0.293 & 0.272 & 0.151 & 0.450 \\
\hline ACTH & 0.125 & 0.171 & -0.041 & -0.089 & 0.339 & -0.026 \\
\hline Glucose & 0.018 & 0.078 & -0.253 & -0.245 & -0.162 & -0.232 \\
\hline \multicolumn{7}{|c|}{ Bold figures denote statistic significance } \\
\hline \multicolumn{7}{|c|}{ B. Coefficients of determination - $\mathrm{R}^{2}$ (F-test $\mathrm{p}$-value) of the six multiple regression equations } \\
\hline & $0 \mathrm{~min}$ & $30 \mathrm{~min}$ & $60 \mathrm{~min}$ & $90 \mathrm{~min}$ & $120 \mathrm{~min}$ & AUC \\
\hline $\mathrm{R}^{2}$ & 0.296 & 0.472 & 0.481 & 0.376 & 0.330 & 0.476 \\
\hline (p) & $(0.103)$ & $(0.007)$ & $(0.006)$ & $(0.035)$ & $(0.071)$ & $(0.007)$ \\
\hline
\end{tabular}


Table 3. Correlations between various parameters during oral glucose tolerance test

\begin{tabular}{|c|c|c|c|c|c|c|c|}
\hline Correlation between: & $\mathbf{n}$ & $0 \mathrm{~min}$ & $30 \mathrm{~min}$ & 60min & $90 \mathrm{~min}$ & $120 \mathrm{~min}$ & AUCa \\
\hline Calcitonin \& Cortisol & 26 & $0.49(0.01)^{\mathrm{b}}$ & $0.65(0.001)$ & $0.27(0.19)$ & $0.27(0.18)$ & $0.19(0.36)$ & $0.47(0.02)$ \\
\hline Calcitonin \& Insulin & 26 & $0.28(0.16)$ & $0.24(0.24)$ & $0.63(0.001)$ & $0.52(0.006)$ & $0.38(0.06)$ & $0.55(0.003)$ \\
\hline Calcitonin \& ACTH & 26 & $0.21(0.31)$ & $0.39(0.05)$ & $0.30(0.14)$ & $0.07(0.73)$ & $0.22(0.28)$ & $0.23(0.25)$ \\
\hline Calcitonin \& Glucose & 26 & $0.19(0.34)$ & $0.33(0.10)$ & $0.11(0.59)$ & $0.02(0.92)$ & $-0.04(0.84)$ & $0.09(0.68)$ \\
\hline Insulin \& Glucose & 26 & $0.31(0.12)$ & $-0.10(0.61)$ & $0.38(0.06)$ & $0.36(0.07)$ & $0.38(0.06)$ & $0.30(0.14)$ \\
\hline Insulin \& Cortisol & 26 & $0.14(0.12)$ & $0.10(0.64)$ & $0.12(0.57)$ & $0.10(0.63)$ & $0.04(0.83)$ & $0.22(0.29)$ \\
\hline Cortisol \& Glucose & 26 & $0.27(0.19)$ & $0.51(0.008)$ & $0.36(0.07)$ & $0.17(0.39)$ & $0.02(0.93)$ & $0.36(0.07)$ \\
\hline Cortisol \& ACTH & 26 & $0.29(0.15)$ & $0.25(0.23)$ & $0.55(0.004)$ & $0.02(0.94)$ & $0.04(0.83)$ & $0.39(0.05)$ \\
\hline ACTH \& Insulin & 26 & $0.33(0.10)$ & $0.06(0.76)$ & $0.36(0.07)$ & $0.14(0.49)$ & $0.22(0.28)$ & $0.22(0.28)$ \\
\hline ACTH \& Glucose & 26 & $0.43(0.03)$ & $0.17(0.40)$ & $0.23(0.26)$ & $0.08(0.69)$ & $0.01(0.97)$ & $0.10(0.64)$ \\
\hline
\end{tabular}

${ }^{\mathrm{a}}$ AUC: Area under curve (0-120 min); ${ }^{\mathrm{b}}: \mathrm{r}(\mathrm{p})$

coefficient $\mathrm{R}^{2}=0.14, \mathrm{p}=0.06$ (Table 3 ).Using multiple regression analysis, a significant relationship was also found between the calcitonin-AUC values and the AUC values of the four independent variables $\left(\mathrm{R}^{2}=0.48, \mathrm{p}=0.007\right)$, but after a stepwise elimination procedure of the non-significant variables, a model was reached with two significant predictors of the calcitonin-AUC, namely insulin-AUC and cortisol-AUC $\left(\mathrm{R}^{2}=0.43, \mathrm{p}=0.002\right)$. The standardized equation of this model was: calcitonin-AUC $=0.474$ insulin-AUC + 0.366 cortisol-AUC; the values of the standard partial regression coefficients (betacoefficients) indicate that the standardized effect of insulin-AUC on calcitonin-AUC was greater than that of cortisol-AUC in this model.

The standard partial regression coefficients in the standardized form of the above six multiple regression equations are summarized in Table 2. It can be seen that in the regression equations concerning $0 \mathrm{~min}$ and $30 \mathrm{~min}$, the beta coefficient for serum cortisol was the highest among the partial standard coefficients of the four independent variables considered here, whereas in the equations concerning values at 60 min, $90 \mathrm{~min}, 120 \mathrm{~min}$, and the AUC values, the beta coefficient for serum insulin was the highest. These findings imply that in normal subjects serum cortisol had the greatest standardized effect among the four predictor variables on basal serum $\mathrm{Ct}$ (at $0 \mathrm{~min}$ ) and early during GTT (at $30 \mathrm{~min}$ ), whereas serum insulin had the greatest standardized effect on serum $\mathrm{Ct}$ during a later phase of the test (60 through $120 \mathrm{~min}$ ).
Thus, at $90 \mathrm{~min}$, for example, for an increase of one standard deviation of basal serum insulin there will be an increase of basal serum Ct by roughly two thirds of its standard deviation, the other independent variables being kept constant (see Table 2).

The results of simple linear correlation between various parameters are summarized in Table 3 . Serum $\mathrm{Ct}$ at all time points passed at least one of the three normality tests. The lack of strong skewness in the $\mathrm{Ct}$ values is presumably due to the fact that subjects with non-detectable $\mathrm{Ct}$ values were excluded. Serum insulin, cortisol, and blood glucose values also passed at least one of the normality tests, while plasma ACTH failed to pass the normality tests. Pearson correlation coefficients were applied among all the parameters except for ACTH. Serum ACTH was correlated with other parameters using Spearman correlation coefficients. It is noteworthy that in the entire group of normal subjects serum Ct was significantly positively correlated with serum cortisol at baseline and at 30 min during GTT, whereas serum $\mathrm{Ct}$ was significantly positively correlated with serum insulin at a later phase of GTT (at 60, 90, and 120 $\mathrm{min}$ ). The calcitonin-AUC was significantly positively correlated with the insulin-AUC as well as with the cortisol-AUC (Table 3, Figure 3). These results are in agreement with the multiple regression results of serum Ct simultaneously on the four independent variables (Table 2). In the normal participants, the regression coefficients $\mathrm{R}^{2}=0.24$ for 0 min values, $\mathrm{R}^{2}=0.42$ for 30 min values, and $\mathrm{R}^{2}=0.22$ for AUC 

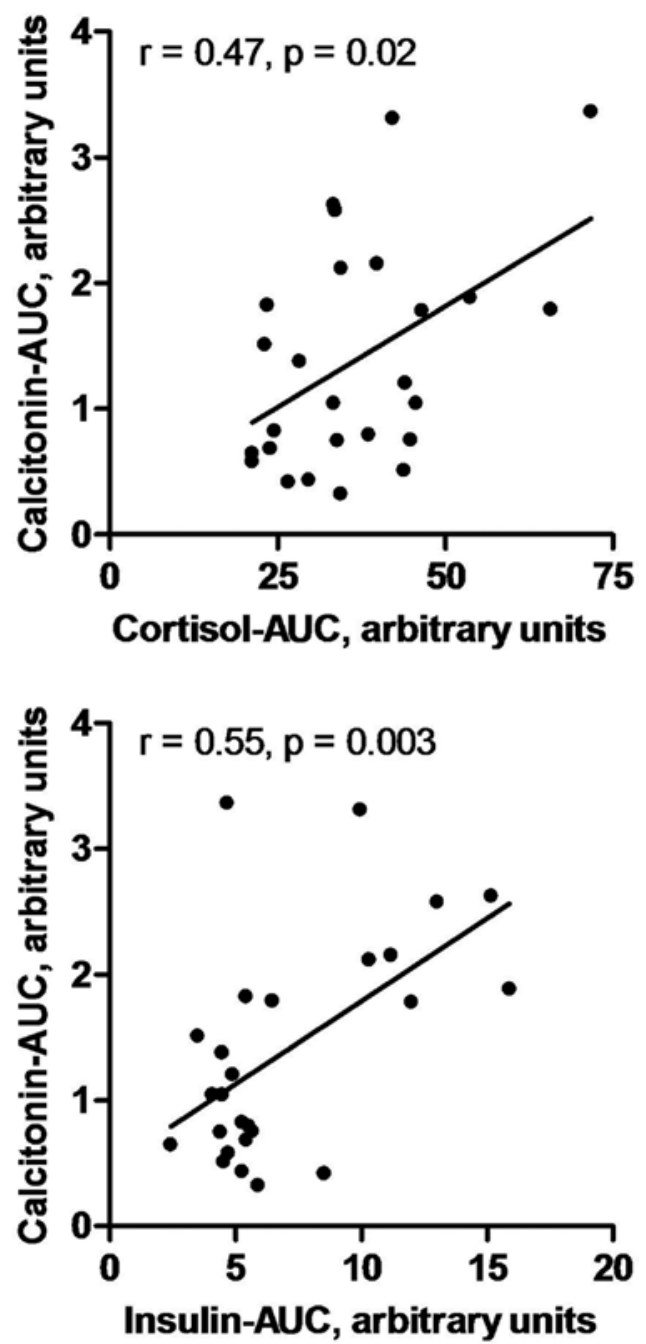

Figure 3. Correlation of calcitonin-AUC with cortisol-AUC, and with insulin-AUC during oral GTT in normal subjects $(n=26)$. The contribution of insulin-AUC to the variance of calcitonin-AUC is greater than that of cortisol-AUC.

values indicate that $24 \%$ of the variance of $\mathrm{Ct}$ at $0 \mathrm{~min}, 42 \%$ at $30 \mathrm{~min}$, and $22 \%$ during the whole duration of GTT was due to serum cortisol. On the other hand, the regression coefficients $\mathrm{R}^{2}=0.40$ at $60 \mathrm{~min}, \mathrm{R}^{2}=0.27$ at $90 \mathrm{~min}$, and $\mathrm{R}^{2}=0.30$ for $\mathrm{AUC}$ indicate that $40 \%, 27 \%$, and $30 \%$ of the variance of serum $\mathrm{Ct}$ was due to serum insulin at these times, respectively (Table 3 ).

\section{DISCUSSION}

Insulin has been shown to stimulate directly $\mathrm{Ct}$ secretion in the pig thyroid. ${ }^{1}$ Dexamethasone has also been shown to stimulate $\mathrm{Ct}$ secretion in vitro in a rat ${ }^{2}$ as well as in a human ${ }^{4}$ MTC tumor cell line. Dexamethasone also increased the production of $\mathrm{Ct}$ mRNA in a human MTC cell line. ${ }^{3}$ The aim of this study was to investigate the response of serum $\mathrm{Ct}$ to hyperinsulinemia induced during an oral GTT in normal subjects and also to assess the relationship between serum $\mathrm{Ct}$ and serum cortisol.

In the normal participants in this study blood glucose and serum insulin increased as expected during an oral GGT. In the entire group mean serum cortisol decreased below its baseline levels at 90-120 min as described previously during GTT; $;, 7$ however, in the entire group of normal subjects of our study a small increase of mean serum cortisol occurred at $30 \mathrm{~min}$, which is not described in previous reports. ${ }^{6,7}$ In fact, in $50 \%$ of the participants mean serum cortisol increased significantly within the normal range of morning serum cortisol, and in the remaining subjects mean serum cortisol decreased significantly during GTT. The reason for these discrepancies is not evident. It is possible that the increase in mean serum cortisol in certain participants in this study may be related to the stress of the procedure affecting these subjects but not others.

The data of the present work showed that during oral GTT median serum Ct increased significantly by approximately $51 \%$ in a group of normal subjects including men and women with detectable basal serum $\mathrm{Ct}$, attaining a peak value at $30 \mathrm{~min}$ after ingestion of the glucose load. This rapid change implies that the mechanism of $\mathrm{Ct}$ stimulation very likely is not genomic. Basal median serum $\mathrm{Ct}$ as well as median calcitonin-AUC were higher in men when compared to women. These results are in agreement with the findings of d' Herbomez et al, ${ }^{8}$ who reported that serum $\mathrm{Ct}$ levels are higher in normal men when compared to women. In the subgroup of participants in whom serum cortisol increased during GTT, serum Ct increased significantly by $42 \%$ at 30 min compared to an increase by $17 \%$ in the participants in whom serum cortisol decreased. These findings indicate that the increase in serum $\mathrm{Ct}$ may be related to the increase in serum cortisol during GTT.

The simple linear regression analysis results in the normal participants in the present study demonstrated that serum $\mathrm{Ct}$ was significantly correlated 
with serum cortisol only before (at $0 \mathrm{~min}$ ) and $30 \mathrm{~min}$ after the ingestion of glucose, whereas serum $\mathrm{Ct}$ was significantly correlated with serum insulin only at 60 $\mathrm{min}, 90 \mathrm{~min}$, and $120 \mathrm{~min}$ (Table 3 ). These results are in agreement with the multiple regression analysis results which showed that the standardized effect of serum cortisol on serum $\mathrm{Ct}$ was higher than that of insulin early during GTT (at 0 and $30 \mathrm{~min}$ ), while the standardized effect of serum insulin on serum Ct was higher than that of cortisol later, at 60, $90 \mathrm{~min}$, and $120 \mathrm{~min}$ (Table 2A). Insulin-AUC and cortisol-AUC were both significantly correlated with calcitoninAUC, the standardized effect of insulin-AUC on calcitonin-AUC being higher than that cortisol-AUC (Tables 2 and 3).

The positive relationship between serum cortisol and serum $\mathrm{Ct}$ at 0 min indicates that there may be a long-term effect of cortisol on $\mathrm{Ct}$ under basal conditions in normal subjects, probably mediated by a genomic mechanism. ${ }^{2,3}$ However, the positive relationship of the peak values of serum $\mathrm{Ct}$ with the peak values of serum cortisol at $30 \mathrm{~min}$ and the co-occurrence of the peak serum concentrations of these two compounds imply that there was also an additional rapid effect of cortisol on Ct during GTT, presumably via a non-genomic mechanism, ${ }^{9}$ although the mean increase of serum cortisol at 30 min was small in the entire group of normal participants in this study. In favor of this view is the fact that progesterone, another steroid hormone, has been shown to stimulate $\mathrm{Ct}$ secretion from TT cells in vitro by a non-genomic rapid mechanism. ${ }^{10}$ An alternative view is that the effect of cortisol on $\mathrm{Ct}$ at $30 \mathrm{~min}$ is not a new activity but an extension of the basal effect of cortisol and the effect at $30 \mathrm{~min}$ is the result of synergy between cortisol and the rising insulin.

A significant positive relationship between high serum insulin and serum $\mathrm{Ct}$ in normal participants was evident with some delay (after min 60 during GTT). This was apparently due to the relatively slow increase of serum insulin which reached a plateau after $60 \mathrm{~min}$. The relationships between serum cortisol and serum Ct early on, and between serum insulin and serum Ct later during GTT, were substantial since approximately 25-45 percent of the variance of serum Ct can be ascribed to cortisol and 30-40 percent to insulin.
The data of our work suggest the existence of an effect of endogenous hyperinsulinemia on $\mathrm{Ct}$ secretion in humans but cannot elucidate whether this effect is direct or possibly mediated also by other pancreatic or gastrointestinal peptides secreted during oral GTT. The results of the experiments carried out by Care et $\mathrm{al},{ }^{1}$ who demonstrated that insulin injected in the thyroid artery of pigs can stimulate directly $\mathrm{Ct}$ secretion, point to a direct effect. The data of the present work showed that serum insulin was not correlated with serum Ct in the basal (fasting) state, but only during induced acute hyperinsulinemia. Serum calcium, the classical Ct secretagogue, seems to behave in an analogous fashion: a constant serum calcium level, even chronic primary hyperparathyroidism-related hypercalcemia does not cause hypercalcitoninemia, ${ }^{11}$ while acute hypercalcemia is a classical $\mathrm{Ct}$ stimulator. As discussed by Clowes et al, ${ }^{12}$ it is not clear whether $\mathrm{Ct}$ secretion increases postprandially. However, it should be noted that the assays used for measuring $\mathrm{Ct}$ in the older literature concerning postprandial secretion of $\mathrm{Ct}^{12}$ were probably not as sensitive and specific for the $\mathrm{Ct}$ monomer as the assay used in the present study.

In the present study we distinguished normal participants with undetectable basal serum $\mathrm{Ct}$ from normal subjects with detectable $\mathrm{Ct}$ and excluded them from the study because, in our experience, a substantial proportion of normal subjects with undetectable serum $\mathrm{Ct}$ fail to respond with a measurable increase of serum $\mathrm{Ct}$ after stimulation with calcium infusion.

In conclusion, we found that under basal conditions there is a positive relationship between serum $\mathrm{Ct}$ and serum cortisol within the physiological range in normal subjects with detectable basal serum Ct. Serum Ct increased during oral GTT, and the positive relationship between serum $\mathrm{Ct}$ and serum insulin implies that $\mathrm{Ct}$ secretion was very likely stimulated by the induced endogenous acute hyperinsulinemia. Since both serum insulin-AUC and serum cortisolAUC were positively correlated with calcitonin-AUC, it seems probable that there is a synergistic effect of insulin and cortisol on Ct secretion during GTT. Physicians should be aware that in states of acute hyperinsulinemia or high but still within normal range serum cortisol, serum calcitonin values may be higher than expected without the presence of these conditions. 
No conflict of interest or financial support declared.

\section{REFERENCES}

1. Care AD, Abbas SK, Pell J, Seitz PK, Cooper CW, 1998 Stimulatory effect of insulin on calcitonin secretion. Horm Metab Res 30: 200-205.

2. Muszynaski M, Birnbaum RS, Roos BA, 1983 Glucocorticoids stimulate the production of preprocalcitoninderived secretory peptides by a rat medullary thyroid carcinoma cell line. J Biol Chem 258: 11678-11683.

3. Cote GJ, Gagel RF, 1986 Dexamethasone differentially affects the levels of calcitonin and calcitonin gene-related peptide mRNAs expressed in a human medullary thyroid carcinoma cell line. J Biol Chem 261: 15524-15528.

4. Lazaretti-Castro M, Grauer A, Raue F, Ziegler R, 1990 1, 25-Dihydroxyvitamin D3 suppresses dexamethasone effects on calcitonin secretion. Mol Cell Endocrinol 71: R13-18.

5. Papapetrou PD, Polymeris A, Karga H, Vaiopoulos G, 2006 Heterophilic antibodies causing falsely high serum calcitonin values. J Endocrinol Invest 29: 919-923.

6. Fernández-Real JM, Ricart W, Casamitjana R, 1997 Lower cortisol levels after oral glucose in subjects with insulin resistance abdominal obesity. Clin Endocrinol 47: 583-588.

7. Cakir M, Sari R, Tosun O, Karayalcin U, 2005 Cortisol levels during glucose tolerance test in lean and obese women. Endocr Res 31: 213-218.

8. d'Herbomez M, Caron P, Bauters C, et al; French Group GTE (Groupe des Tumeurs Endocrines) 2007 Reference range of serum calcitonin levels in humans: influence of calcitonin assays, sex, age, and cigarette smoking. Eur J Endocrinol 157: 749-755.

9. Stahn C, Buttgereit F, 2008 Genomic and nongenomic effects of glucocorticoids. Nat Clin Pract Rheumatol 4: 525-533.

10. Lu CC, Tsai SC, 2007 The cyclic AMP-dependent protein kinase A pathway is involved in progesterone effects on calcitonin secretion from TT cells. Life Sci 81: 1411-1420.

11. Conte-Devois B, Morlet-Barla N, Roux F, Sebag F, Henry JF, Niccoli P, 2010 Could primary hyperparathyreoidismrelated hypercalcemia induce hypercalcitoninemia? Horm Res Pædiatr 73: 372-375.

12. Clowes JA, Khosla S, Eastell R, 2005 Potential role of pancreatic and enteric hormones in regulating bone turnover. J Bone Miner Res 20: 1497-1506. 